\title{
SULPHUR BUTTERFLIES \\ OF THE Colias alexandra COMPLEX IN ALBERTA
}

NORBERT G. KONDLA, Box 762, McBride, British Columbia. VOJ 2E0

The Colias alexandra complex consists of butterfly populations that are widely distributed in western North America (see Ferris or Scott for a range map). ${ }^{23,53}$ A substantial literature has developed on this insect and the various taxa that have been treated as part of this complex in the contemporary literature have been the subject of "taxonomic football." Ferris provides a synonymy. ${ }^{23}$ The purpose of this paper is to review what has been published about this complex in Alberta, describe the situation that actually exists in Alberta, and present an argument for recognizing Colias alexandra (Queen Alexandra Sulphur) and Colias christina (Christina Sulphur) as distinct species.

The name Colias alexandra is used here in the qualified sense of Kondla as the best name available. ${ }^{36}$

Historical Taxonomy Summary The taxa relevant to Alberta were described by W. H. Edwards in 1863 and 1872, Klots in 1935, and Bowman in $19422^{7,13,14,15,34}$ In 1863, the taxon alexandra ${ }^{14}$ was described from material collected in the region west of Denver, Colorado. ${ }^{9}$ Later that year, Colias christina was described as a new species with type material from "the portage of the Slave River." ${ }^{14}$ Kondla (in press) has clarified this type locality as being the vicinity of Mountain Rapids, Slave River, Alberta. Edwards introduced the name astraea as a new species based on a single male collected near Yellowstone Lake. ${ }^{15}$ Klots added the name krauthii to the literature as a subspecies of christina. ${ }^{34}$

The taxon alberta was described as a subspecies of eurytheme. $^{7} \quad$ Ferris viewed it as a hybrid situation, while Miller and Brown treated it as a synonym for eurytheme. ${ }^{21,45}$ । side with Hovanitz and Masters in treating it as a synonym for $C$.

christina. ${ }^{30,39,41}$

Except for a listing as a subspecies of $C$. occidentalis, the name alexandra has survived the attention of various writers essentially unmolested. ${ }^{44}$ The synonymy provided by Ferris shows that fate was not kind to the other taxa. ${ }^{23}$ It did not take long for Stecker to align christina with pelidne. In 1878, Skinner moved 
christina back to species status, where it remained until the early 1960s. At this time, McHenry associated it with $C$. occidentalis and Dos Passos shifted christina to a subspecies of alexandra. ${ }^{12}$ Astraea survived as a species in the literature until 1898 when Skinner placed it as a subspecies of christina. In 1949, Holland reverted to species status for astraea. Again, in the 1960s strange things happened. Astraea was variously placed as a subspecies of occidentalis, scudderi and alexandra. Krauthii has a somewhat cleaner history. It was not tinkered with for some 20 years, when it was moved to a subspecies of occidentalis and then alexandra.

The mass migration of christina, astraea and krauthii to their status as subspecies of alexandra appears to originate from the treatment of Ehrlich. ${ }^{17}$ Dos Passos made these assignments explicit. $^{12}$ I have been unable to find any published arguments or data to support this arrangement.

This chapter of the story therefore leaves us in a situation where the conventional wisdom as reflected in the literature places taxa relevant to Alberta in the species Colias alexandra.

Characteristics of the Taxa Additional murkiness and confusion confront naturalists and lepidopterists when attempting to do something as apparently simple as using the literature to identify and attach some names to Alberta specimens. In random order, here is a smattering of what one finds when trying to attach descriptions to the names alexandra, christina and astraea:

\section{alexandra}

- Ferris - yellow (concolorous with the ground colour) dorsal spots on the dorsal surface of the secondaries in the males; 22

- Pyle - some northern populations are orange; forewing yellow fringed; brighter yellow spot in hindwing cell; narrow black forewing and hindwing border; unrimmed cell spot on ventral hindwing; female yellow or white; refers to Alberta populations as "yellow populations"; wingspan 3.8$4.8 \mathrm{~cm}$;

- Royer - ventral hindwing with much reduced discal spot (always poorly outlined); narrow dorsal borders; females usually have no dorsal hindwing border at all; white females occur; $4-5.5 \mathrm{~cm}$ wingspan; ${ }^{52}$

- Brown - pale yellow upperside and cool, pale greyish green on ventral hindwing; albino females are rare; female black borders vague but rarely absent; straight outer margin of forewing; yellow wing fringes; 8

- Ferris and Brown - male bright lemon yellow and female warmer yellow; ventral hindwing dusted with greenish grey scales; ventral hindwing discal spot unrimmed and usually quite small; white females occur in some colonies; ${ }^{24}$

- Howe - light bright yellow above, deepening to a warmer yellow outward to the dark border, especially of the hindwing; fringes yellow; no orange discal spot above; ventral hindwing grey-green to slaty grey with no rim on discal spot; 33

- Scott - ventral hindwing is greyish with a silver spot lacking a rim; fringes yellow; wings yellow;

- Tilderi and Smith - referring generally to yellow subspecies: dorsal 
bright yellow in male, paler near wing bases; black border narrow, crossed by yellow veins; dorsal forewing cell spot usually small; dorsal hindwing discal spot inconspicuous but present; female yellow, occasionally white; ventral: hindwing greenish grey in both sexes; discal spot white with no ring; wing edge yellow, seldom pink. 56

\section{christina}

- Howe - presumably all orange but cannot be sure; ${ }^{33}$

- Scott - orange on outer half of dorsal hindwing and outer $2 / 3$ of dorsal forewing; ventral hindwing often has submarginal spots and rarely a central satellite spot; ${ }^{53}$

- Hooper - females more yellow and some of them albinistic, their hindwings almost or entirely lacking black margins; males orange above with a wide band of sulphur yellow across the base of each wing; silver spot in middle of hindwing beneath; ${ }^{29}$

- Ferris - somewhat variable in phenotype, considerable colour variation occurs in both sexes; some males completely orange and some females white form; dorsal wings of 'classical' male basally yellow and distally orange, colour transition abrupt; dorsal female wings generally yellow with an orange blush; ${ }^{23}$

- Masters - males extremely regular in appearance while females are extremely variable; 36 females from near the type locality were roughly $1 / 3$ orange, 1/3 yellow, 1/3 white; female black bands absent to complete. ${ }^{42}$

\section{astraea}

- Ferris and Brown - males vary from warm yellow through orange and yellow to orange with a small amount of yellow basally; orange dorsal hindwing discal spot; females vary from pure white to overwashed with pink and orange; ${ }^{24}$

- Howe - variously mixed yellow to orange populations; yellow individuals, often predominant locally, have an orange discal spot on the dorsal hindwing; ${ }^{33}$

- McDunnough - white females; ventral hindwing discal spot not entirely constant, can be single or double; ${ }^{43}$

- Gerould - extreme variability in females; "most bewildering variety of colours," "wonderfully variable species";,27

- Hovanitz - variation ranging from full yellow to bright orange in Waterton area; ${ }^{32}$

- Hovanitz - frequency of white females about $70 \%$; 30

- Scott - the description given under christina is applied to Alberta in total; 53

- Tilden and Smith - usually a blend of orange and yellow; referring generally to orange subspecies; dorsal: "Male distinctively twotoned, orange with yellow at wing bases and costa. Female duller orange, usually heavily marked with dark borders and dark veins"; ventral: "dull orange to greenish grey in both sexes; often much dark overscaling. HW discal spot usually ringed." 56 


\begin{tabular}{|c|c|c|c|c|}
\hline $\begin{array}{l}\text { WHITE VS. } \\
\text { FROM VAR }\end{array}$ & $\begin{array}{l}\text { RANGE F } \\
\text { RTA LOC }\end{array}$ & $\begin{array}{l}\text { ALES } \\
\text { TIES }\end{array}$ & & \\
\hline Location & $\begin{array}{l}\text { yellow/ } \\
\text { orange }\end{array}$ & white & total & $\%$ white \\
\hline Ft. Smith-Fitzgerald & 73 & 0 & 73 & 0 \\
\hline Pocahontas, 1948 & 8 & 21 & 29 & 72.4 \\
\hline Pocahontas, 1947 & 18 & 24 & 42 & 57.1 \\
\hline Mountains (unspecified) & 3 & 13 & 16 & 81.3 \\
\hline Banff & 66 & 39 & 105 & 37.1 \\
\hline Calgary & 25 & 20 & 45 & 44.4 \\
\hline Calgary, 1948 & 1 & 1 & 2 & \\
\hline Macleod Junction & & 1 & 1 & \\
\hline Didsbury & 14 & 12 & 26 & 46.2 \\
\hline Waterton Lakes & 4 & 2 & 6 & 33.3 \\
\hline Laggan [Lake Louise] & 23 & 13 & 36 & 36.1 \\
\hline
\end{tabular}

For specific Alberta locations, here is what has been written:

- Masters - "A series of 36 males and 36 females of topotypical northern Alberta Colias christina (at Carnegie Museum) displayed slightly smaller size. Alberta males had a median forewing length of 24 $\mathrm{mm}$, with the average slightly more than $24 \mathrm{~mm}$; the range was between 22 and $27 \mathrm{~mm}$. Alberta females had a median forewing length of $26 \mathrm{~mm}$, with the average being slightly less that $26 \mathrm{~mm}$; the range was between 19 and $29 \mathrm{~mm}$; of the Alberta sample of nominate christina, only $27.8 \%$ of 36 females were orange, while $30.6 \%$ were yellow and $41.8 \%$ were white; ... the Alberta sample of 36 females contained $19.4 \%$ with immaculate wings, $44.4 \%$ with apex bands only, $22.2 \%$ with outer bands only and $13.4 \%$ with complete bands"; 42

- Hovanitz - provided data on the prevalence of white vs. yellow/ orange females in samples from various Alberta localities (Table $1)^{30}$

- Ferris - map assigning most of eastern 2/3 of province to christina with a minor intrusion of astraea on the prairies and the rest of the province to intergrade forms: "Southern Alberta appears to represent a complex blend zone region. In the area from Calgary to Banff and east of the Rocky Mountains, specimens can be taken which represent alexandra, astraea, christina and krauthii. It is frequently possible to collect two or three good 'subspecies' at the same locality"; "Pure orange races of alexandra have been reported from the area near ... Pocahontas, Alberta. ... the Alberta specimens superficially resemble krauthii but are considerably smaller"; 22

- Ferris - "blend zone areas where all phenotypes can be collected in the same meadow (such as the Kananaskis Forest region south of Banff"; referring to astraea, "This phenotype occurs in southern Alberta (in the foothills west of Calgary and north to the Banff region)"; includes a map showing alexandra complex as being absent from much of northeastern Alberta (including the type locality of christina); ${ }^{23}$

- Hovanitz - in reference to waterways and areas to the north, "Toward the middle of July, $C$. 


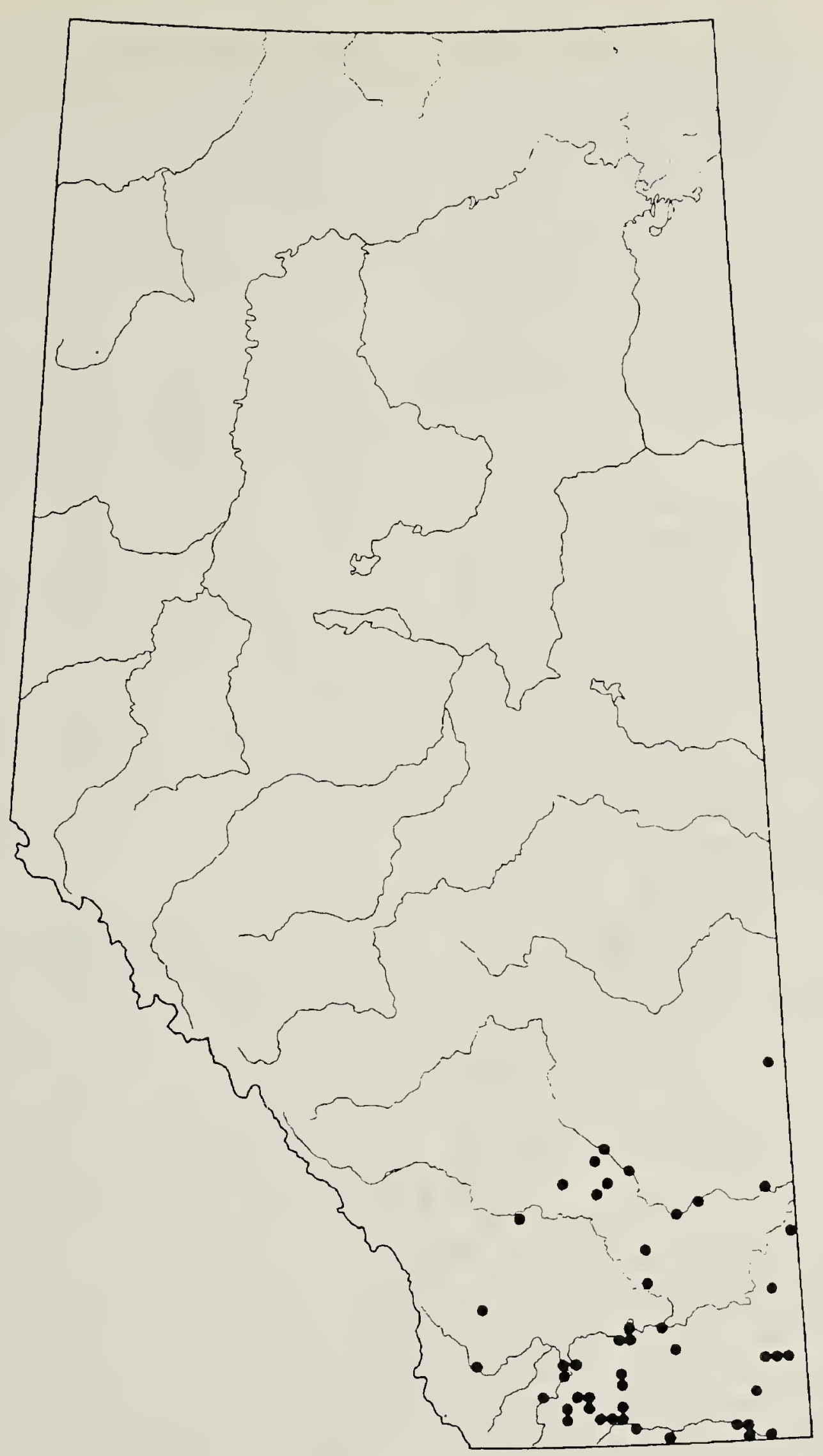

Figure 1. DISTRIBUTION OF Colias alexandra IN ALBERTA.

gigantea adults are replaced largely by those of C. christina"; in reference to Jasper and vicinity, "Colias christina occurs only below 5,000 feet in elevation and is most common in late July"; 31

- Hovanitz - "Populations ... from the north and east of [Waterton Lakes area] are generally orange or orange-yellow in the male"; ${ }^{32}$
- Wolley Dod - "The females show most extraordinary variation. It is hard to find two alike"; 58

- Wolley Dod - referring to the area around Calgary, "scarcely any two (series of 30) even nearly alike in either colour or markings, much variation in male border."

As well the following papers report 


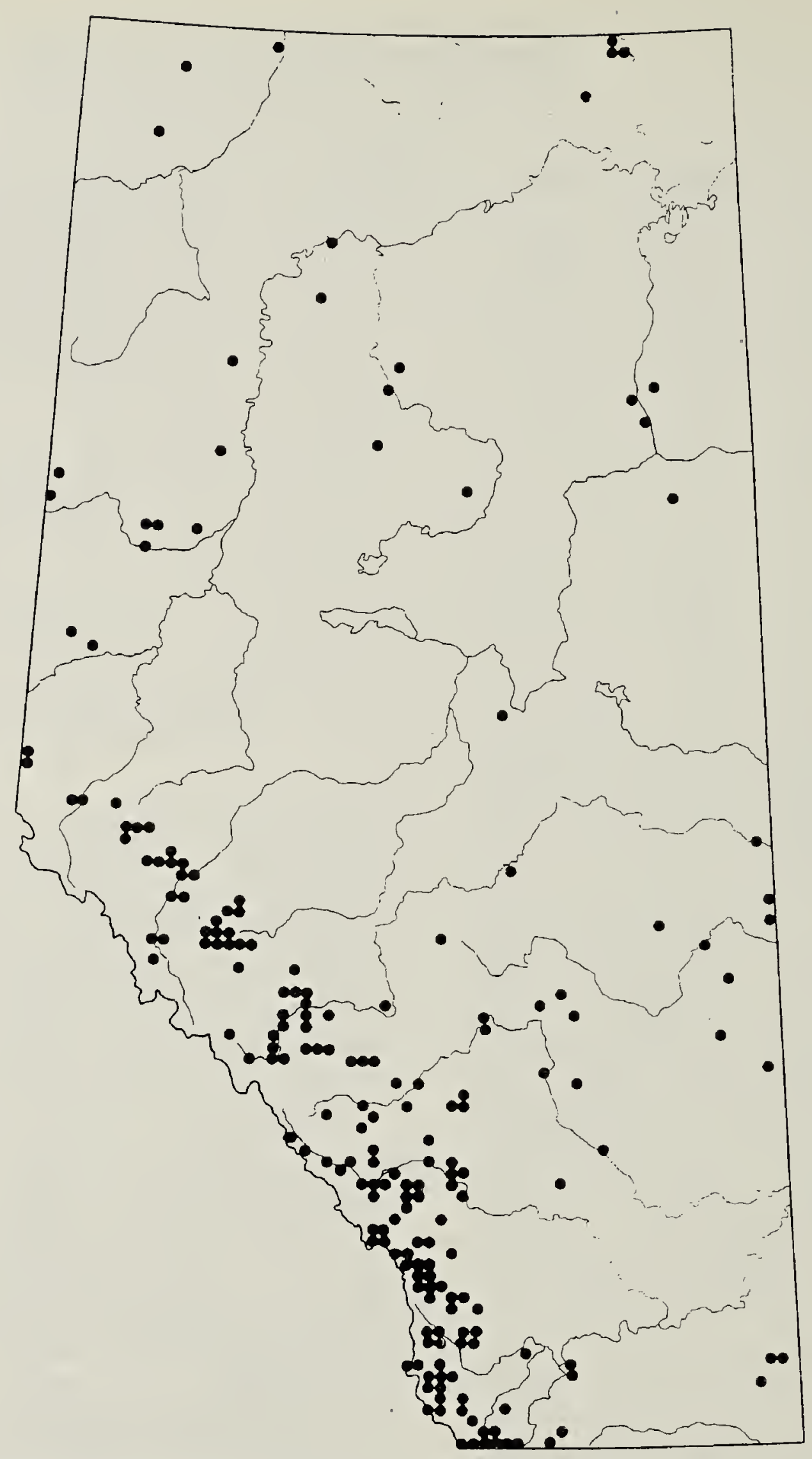

Figure 2. DISTRIBUTION OF Colias christina IN ALBERTA.

the occurrence of christina and alexandra at various Alberta locations: Anderson ${ }^{1}$; Bird ${ }^{2}$; Bird et al. ${ }^{3}$; Bowman $^{4,5,6,7}$; Cary ${ }^{10}$; Case and Bird ${ }^{11}$; Eff $^{16,17,18,19,20}$; Ferris ${ }^{21,22,23}$; Geddes $^{25,26}$; Hovanitz ${ }^{30}$ Klots ${ }^{34}$; Kondla ${ }^{35,36,37,38,39}$; McDunnough ${ }^{43}$; Nicholl ${ }^{46}$; Pinel ${ }^{47,48,49}$; Pinel and Kondla ${ }^{50}$; Thormin, Kondla and Bird $^{55}$; Whitehouse ${ }^{57}$; and Wolley Dod. $^{58,59,60}$
Most reasonable people would look at such inconsistent and contradictory descriptive material (along with the supporting illustrations) and derive, for example, the following conclusions: males are yellow or orange or something in between; females are white or yellow or orange or some combination thereof; the black wing borders are narrow or wide; populations are variable in ap- 
pearance or they are not; the hindwing underside may or may not have submarginal spots; the ventral hindwing dorsal spot may be orange or it may not; the ventral hindwing discal spot maybe silver or white and it may or may not have a satellite spot, etc.

Curious indeed. One could suppose that various authors are describing different species rather than a single species. Using the existing literature on what appearance (phenotype) is associated with various names, one would be successful if they attached the name alexandra to a yellow male, flipped a coin and called a yellow/orange or mostly orange male astraea, christina or krauthii, and threw a planning dart at a female and called it a Colias species unknown.

Fortunately all is not lost. Both species and subspecies names usually have a spatial (geographical) dimension and a phenotypic dimension. That is to say, by knowing where you caught, photographed or saw a critter, you can eliminate names that have a traditional geographic definition remote from the record under consideration. For example, a bug that looks like krauthii caught in southwestern Alberta obviously is not krauthii since this name is spatially defined as referring to bugs in the Black Hills of South Dakota. You can feel safe in knowing that a Colias from southwestern Alberta with at least some orange on it is probably astraea unless of course it is eurytheme or canadensis or meadii.

Confused or misled? Of course! This statement is not a reflection on the work of many people who have researched the alexandra complex. It is an example of biological and taxonomic research at work. Field work; measurements; descriptions; publication of data; publication of opinions and speculation to foster more data collection; interpretation based on differing concepts and researcher backgrounds; conflicting interpretation based on differing data sets, analytical techniques, and spotty data sets, etc.; the list of reasons for disparate statements goes on and on.

\section{A Local View of the Alberta}

Situation I became suspicious about the reported status of the Colias a/exandra complex in 1978 when I caught a specimen of that species near Standard. ${ }^{35}$ At that time alexandra was unreported in the literature for any specific Alberta location. The authoritative treatment of the day (Ferris) clearly indicated that I should have caught christina but that I could expect specimens that would be equally at home under the names astraea, alexandra or krauthii. ${ }^{22}$ With a bit of additional field research around the province it soon became obvious that reality was in fact not as reported in the literature.

My personal work in Alberta over a 20 year period was supplemented by an exhaustive literature search that has yielded close to 400 references on Alberta butterflies and also by data collected by others. Particularly significant data have been provided by C.D. Bird, G. Hilchie, E.M. Pike, H. Pinel, S. Shigematsu and F.A.H. Sperling. The complete data base from which information was used represents contributions from nearly 300 individuals.

Regardless of which names will be shown to be correct by further research, there definitely appear to be two distinct species in the province. Figure 1 shows the distribution I have been able to document for $C$. 
alexandra and Figure 2 shows the situation for C. christina.

By comparing these distribution maps with a map of ecoregions it is immediately clear that alexandra is essentially a prairie grassland insect and that christina is essentially a woodland insect. From a distribution and geographic perspective this reality suggests (and field work confirms) that there is in fact no broad band of intergradation, zone of intergradation or blend zone region as reported in the literature. This macro-scale forest and grassland distinction also holds up on a site basis. Most of the prairie occurrences of christina and astraea phenotypes are places where forest and grassland habitats are in juxtaposition.

The phenology (time of adult flight) of these two species is very interesting. The data set was examined from the perspective of stations and abundance. A station is defined as a report of butterfly occurrence at a single place on a single day. Abundance is synonymous with specimen count. Both station frequency and total abundance were plotted against phenology units for each month of the flight season. A phenology unit is defined as early, mid-, or late month as follows: early - days 1-10; mid days 11-20; late - days 21-31. Since butterfly phenology is known to vary with latitude and altitude, the data set for christina was stratified according to the following scheme to account for regional differences: prairies, aspen parkland, boreal forest, southern mountains, and northern mountains. The Bow River valley was used as the northern terminus of the southern mountains region.

Colias alexandra extreme flight dates are 13 May and 1 September. The data show a very pronounced bimodal pattern consistent with a bivoltine (two brooded) butterfly. In fact, the break between broods is more substantial than illustrated by graphed data. No records of this species are available between 3 July and 23 July.

In contrast, the smaller christina data set shows a clear unimodal pattern consistent with a univoltine (single brooded) butterfly. Individuals of these taxa peak during the time window (mid-July) when alexandra is not known to fly. The small boreal forest christina data set also indicates a univoltine situation but with a peak flight in early July. The much more substantive aspen parkland sample again indicates a univoltine creature with a pronounced flight in mid-July.

The very substantial samples from the southern mountains and the northern mountains are congruent and show that christina is univoltine here as well. Peak flights are in midJuly. The abundance data also suggest that the butterfly is more abundant (where it occurs) in the northern mountains than it is in the southern mountains. This is in agreement with my own qualitative field observations. Extreme early and late flights for christina in the province are 10 May and 26 September.

Table 2 presents the readily observable differences between the taxa alexandra and christina (including astraea-like phenotypes) in Alberta. It does not include less observable differences requiring equipment for scrutiny nor differences in immature stages.

These differences are more dramatic than the differences between, for example, C. pelidne and C. philodice. Given the distributional, 
Table 2. COMPARISON OF Colias christina AND Colias alexandra IN ALBERTA.

\begin{tabular}{|c|c|}
\hline Colias christina & Colias alexandra \\
\hline $\begin{array}{l}\text { males variable but usually extensive orange } \\
\text { areas on dorsal surface in at least } 99 \% \text { of } \\
\text { individuals }\end{array}$ & $\begin{array}{l}\text { males with no orange areas on dorsal surface, } \\
\text { yellow except for black forewing discal spot and } \\
\text { marginal band }\end{array}$ \\
\hline male dorsal yellow areas of a lemon hue & males with dorsal cold yellow hue \\
\hline $\begin{array}{l}\text { male ventral hindwing mostly yellow in boreal } \\
\text { region, mostly greenish elsewhere }\end{array}$ & male ventral hindwing greyish green \\
\hline $\begin{array}{l}\text { ventral hindwing discal spot larger and with red } \\
\text { rim, frequent satellite spot in north }\end{array}$ & $\begin{array}{l}\text { ventral hindwing discal spot smaller and does } \\
\text { not have a red rim, no satellite spot }\end{array}$ \\
\hline $\begin{array}{l}\text { frequent ventral submarginal spots in boreal } \\
\text { populations (especially in males) }\end{array}$ & no ventral submarginal spots \\
\hline dorsal hindwing with large orange discal spot & $\begin{array}{l}\text { dorsal hindwing without a discal spot, } \\
\text { appearance of small pale spot is optical illusion } \\
\text { due to ventral hindwing spot }\end{array}$ \\
\hline wing fringes mostly pink & wing fringes yellow \\
\hline males larger, FW length mostly $25-27 \mathrm{~mm}$ & male dorsal FW length mostly $22-23 \mathrm{~mm}$ \\
\hline $\begin{array}{l}\text { male dorsal FW black border wider, generally } \\
3.5 \mathrm{~mm} \text {. }\end{array}$ & $\begin{array}{l}\text { males smaller, FW black border generally } \\
\text { narrower, } 2 \mathrm{~mm}\end{array}$ \\
\hline $\begin{array}{l}\text { females extremely variable in size, colour } \\
\text { (yellow, orange, white or any combination } \\
\text { thereof), amount of black dorsal marginal scaling }\end{array}$ & $\begin{array}{l}\text { females consistent in size, } 99 \% \text { white, minimal } \\
\text { black dorsal marginal scaling }\end{array}$ \\
\hline antennae pink & antennae pale buff \\
\hline $\begin{array}{l}\text { dorsal forewing black band with yellow-orange } \\
\text { overscaling; makes band look grey in fresh } \\
\text { individuals }\end{array}$ & $\begin{array}{l}\text { dorsal forewing black band without coloured } \\
\text { overscaling }\end{array}$ \\
\hline univoltine & bivoltine \\
\hline $\begin{array}{l}\text { found in boreal forest, mountains and some } \\
\text { fescue prairie areas }\end{array}$ & $\begin{array}{l}\text { found in prairie grasslands and some dry } \\
\text { foothills grasslands }\end{array}$ \\
\hline
\end{tabular}

phenotypic, ecological, and phenological differences between these taxa, it is reasonable to conclude that they are in fact separate and distinct species. Both taxa were originally described as distinct species and various literature that treats them as one species does not provide solid support for such treatment. The highly variable $C$. christina populations of the southern mountains seem to have been misinterpreted by various researchers as evidence of intergradation between the taxa.

In Alberta $C$. alexandra is a remarkably consistent species. Specimens differ from the nominate subspecies in the following characteristics: smaller size, narrower forewing black borders, darker greyish green ventral hindwing, and almost all females white. These differences are more substantial than the differences between the nominate subspecies and subspecies apache which was described by Ferris. ${ }^{23}$ Consequently these "prairie" populations which are known from the plains of Alberta, Saskatchewan, Montana, and North Dakota should be described as a new subspecies. Until such time as transitional populations to $C$. alexandra alexandra are documented, the possibility of separate species status for these prairie populations should not be categorically ruled out. Alberta populations of C. alexandra completely lack any dorsal hindwing discal spots which some literature deems to be a consistent characteristic of all Colias species. North American literature has traditionally claimed that this discal spot is concolorous with the ground colour but close examination 
shows that in fact there is no discal spot.

The variability, within and between populations, of $C$. christina makes general characterization over the whole province a real challenge. Some regional trends in Alberta are: boreal forest populations tend to be smaller, have a yellow ventral hindwing, frequently have ventral hindwing satellite spots and submarginal spots, and have a larger proportion of yellow and orange females; parkland populations are larger, have a pale greenish ventral hindwing; southern mountain populations are larger, have a greenish ventral hindwing and most females are white; the Mountain Park area in the northern mountains supports distinctive populations that are smaller, dark green on the ventral hindwing, frequently have substantial dark scaling on the basal portion of the dorsal hindwing, and most females are white. Many male specimens from the Mountain Park area resemble $C$. christina kluanensis (a Yukon subspecies) more than any other named subspecies.

The archtypal phenotype of nominate male $C$. christina is that of a dorsal surface with a sharply divided, deep, bright orange outer half and a bright yellow basal portion (e.g., Gil$\left.l e_{t e}^{28}\right)$. Such individuals do occur in all sampled populations of $C$. christina in Alberta, except the Mountain Park populations where the bright yellow basal portion of the dorsal hindwing is mostly replaced with melanic scaling. These archtypal phenotypes are however a minority in sampled populations. Examination of a long series shows that variation runs from occasional individuals that are all yellow to those that are almost all orange. The most frequent male phenotype is a butter- fly that is roughly one-half orange and one-half yellow on the dorsal surface with the orange of a paler hue and with an ill-defined transition from yellow to orange in comparison to the archtypal phenotype.

There remains then the problem of suitable names to attach to Alberta material. For the purpose of communicating the general appearance of individuals there is no problem. The existing names (alexandra, astraea, krauthii, and christina) can be used as convenient "handles" to communicate that the specimen at hand is consistent in phenotype with the characteristics normally associated with the name.

Attaching names in a true taxonomic sense is an unresolved problem at the time of writing. There are no published data to support lumping of the yellow prairie insect with nominate $C$. alexandra. Information presented herein suggests it is at least a distinct subspecies that should be formally described and given a name. The appropriateness of using the name astraea to refer to the southern mountain populations also needs to be critically reviewed. Again no published data exist to support lumping of Alberta material with populations from the vicinity of the type locality, at least not at the subspecies level. Ferris attributes astraea to Alberta but does not provide data to refute the equally unsubstantiated and contradictory opinion of Masters who states that southern Alberta and Alberta mountain populations are "statistically at least distinct from typical astraea from Wyoming."21,23,41 At this time only the name christina can be confidently used as a species and subspecies name to reference the yellow/orange and mostly orange populations of the boreal forest. 
1. ANDERSON, R.L. 1960. A collecting trip to the Nordegg area, July 4 and 5 , 1960. Proceedings of the eighth annual meeting of the Entomological Society of Alberta. Pp. 14-16.

2. BIRD, C.D. 1975. Rhopalocera in the N.B. Sanson collection. Journal of the Lepidopterists' Society 30:201-206.

3. BIRD, C.D., G.J. HILCHIE, N.G. KONDLA, W.W. SMITH, E. KUYT, J.K. RYAN and T.W., THORMIN. 1982. Butterflies of northeastern Alberta. Blue Jay 40:141-53.

4. BOWMAN, K. 1919. Annotated checklist of the macrolepidoptera of Alberta. Alberta Natural History Society, Red Deer. 16 pp.

5. - 1921. Annotated check list of the macrolepidoptera of Alberta. Additions, 1919. Can. Ent. 53:13-14.

6. 1923. Annotated check list of the macrolepidoptera of Alberta. Additions, 1921. Can. Ent. 55:71-72.

7. 1942. A note of the Colias eurytheme Bdv., with description of a new race (Lepidoptera:Pieridae). Can. Ent. $74: 25$.

8. BROWN, F.M., D. EFF and B. ROTGER. 1957. Colorado butterflies. Dienver Museum of Natural History, Denver, Colorado. 368 pp.

9. BROWN, F.M. 1973. The types of the pierid butterflies named by William Henry Edwards. Transactions of the American Entomological Society 99: 29-118.

10. CARY, M. 1906. On the diurnal lepidoptera of the Athabasca and MacKenzie regions, British America. Proceedings of the United States National Museum 31:425-57.

11. CASE, J.W. and C.D. BIRD. 1977. Butterflies and skippers of westcentral Alberta. Blue Jay 35: 208-19.

12. DOS PASSOS, C.F. 1964. A synonymic list of the neararctic Rhopalocera. Lepidopterists' Society Memoir No. 1. 145 pp.
13. EDWARDS, W.H. 1863a. Descriptions of certain species of diurnal lepidoptera found within the limits of the United States and British America No. 1. Proceedings of the Entomological Society of Philadelphia 2:14-22.

14. - 1863b. Descriptions of certain species of diurnal lepidoptera found within the limits of the United States and British America No. 2. Proceedings of the Entomological Society of Philadelphia 2:78-82.

15. 1872. Miscellaneous notes of butterflies, larvae, etc. Can. Ent. 24:105-11.

16. EFF, D. 1950. (coordinator). Rocky Mountains - New Mexico, Utah, to Alberta. Pp. 93-96 in The field season summary of North American iepidoptera for 1950. Lepidopterists' News 4:85-107.

17. - 1962. (coordinator). Season's summary. Zone III. Rocky Mountains area: Alberta, Wyoming, Utah, Colorado and New Mexico. News of the Lepidopterists' Society 3: 4-7.

18. - 1967. (coordinator). Season's summary. Zone III. Rocky Mountains area: Alberta, Wyoming, Utah, Colorado and New Mexico. News of the Lepidopterists' Society 3: 6-8.

19. - 1968. (coordinator). Season's summary. Zone III. Rocky Mountains area: Alberta, Wyoming, Utah, Colorado and New Mexico. News of the Lepidopterists' Society 3: 9-11.

20. - 1974. (coordinator). Season's summary. Zone III. Rocky Mountains area: Alberta, Wyoming, Utah, Colorado and New Mexico. News of the Lepidopterists' Society 2: 4-6.

21. FERRIS, C.D. 1972. Notes of certain species of Colias (Lepidoptera:Pieridae) found in Wyoming and associated regions. Bull. of the Allyn Mus. 5:1-23.

22. - 1973. A revision of the Colias alexandra complex (Pieridae) aided by ultraviolet reflectance photography 
with designation of a new subspecies. $\mathrm{J}$. of the Lepidopterists's Society 27:57-73.

23. - 1988. Revision of several Leguminosae-feeding Colias species, with description of a new subspecies (Pieridae:Coliadinae). Bull. of the Allyn Mus. 116:1-28.

24. FERRIS, C.D. and F.M. BROWN. 1981. (eds.). Butterflies of the Rocky Mountain States. Univ. of Oklahoma Press, Norman. 442 pp.

25. GEDDES, G. 1883. List of diurnal Lepidoptera collected in the Northwest Territory and the Rocky Mountains. Can. Ent. 15:221-23.

26. - 1889. Notes for collectors visiting the prairies and Rocky Mountains. Can. Ent. 21:57-58.

27. GEROULD, J.H. 1923. Inheritance of white wing color, a sex-limited (sexcontrolled) variation in yellow pierid butterflies. Genetics 8:495-551.

28. GILLETTE, C.F. 1989. A revision of the "megalithic" Colias alexandra complex (Pieridae:Rhopalocera:Lepidoptera) with the discovery of a newly recognized species of Colias in Utah. Utahensis 7:31-60.

29. HOOPER, R.R. 1973. The butterflies of Saskatchewan. Saskatchewan Mus. of Natural History, Regina. 216 pp.

30. HOVANITZ, W. 1950. The biology of Colias butterflies. II. Parallel geographical variation of dimorphic color phases in North American Species. Wasmann J. of Biology 8:197-219.

31. - 1951. The biology of Colias butterflies. III. Variation of adult flight in the Arctic and Subarctic. Wasmann J. of Biology 9:1-9.

32. - 1965. Colias christina - alexandra intergradation. J. of Research on the Lepidoptera 4: cover illustration with caption.

33. HOWE, W.H. 1975. (ed.). The butter- flies of North America. Doubleday, New York. 632 pp.

34. KLOTS, A.B. 1935. A new Colias from South Dakota (Lepidoptera:Pieridae). American Museum Novitates 767:1-2.

35. KONDLA, N.G. 1979. Skippers and butterflies of a prairie farm. Alta. Nat. 9:71-75.

36. - 1981. Skippers and butterflies of a disjunct aspen parkland area in Alberta. Blue Jay 39:4-12.

37. _ 1983. Additional records of skippers and butterflies from Dinosaur Provincial Park. Alta. Nat. 13:152-57.

38. - 1986. Skippers and butterflies of the Kootenay Plains, Alberta. Alta. Nat. 16:11-14.

39. - 1991. A discussion of the correct status of Colias eurytheme alberta. Utahensis 6:44-45.

40. I In press. The type localities of Colias christina Edw. and Oeneis caryi Dyar. Utahensis.

41. MASTERS, J.H. 1970. Concerning Colias eurytheme alberta Bowman (Pieridae). J. of Research on the Lepidoptera 4:149-57.

42. - 1975. Variation in Colias alexandra christina Edwards (Pieridae) in southwest Manitoba. J. of Research on the Lepidoptera 9:97-99.

43. MCDUNNOUGH, J.H. 1922. Notes on the Lepidoptera of Alberta. Can. Ent. 54:134-41.

44. MCHENRY, P. 1962. The generic, specific and lower category names of the nearctic butterflies. J. of Research on the Lepidoptera 1:209-21.

45. MILLER, L.D. and F.M. BROWN. 1981. A catalogue/checklist of the butterflies of America North of Mexico. The Lepidopterists' Society Memoir No. 2. 280 pp.

46. NICHOLL, MRS. [DE LA B.] 1906. Butterfly collecting in Canada, 1904. 
Annual Report of the Entomological Society of Ontario 1905. 36:70-80.

47. PINEL, H.W. 1983. Skippers and butterflies of the Indian Grove Campground area, Alberta. Blue Jay 41:71-77.

48. 1985. Skippers and butterflies of the Crimson Lake Provincial Park, Alberta. Blue Jay 43:155-59.

49. - 1988. Skippers and butterflies of Bow Valley Provincial Park, Alberta. Alta. Nat. 18:7-10.

50. PINEL, H.W. and N.G. KONDLA. 1985. Skippers and butterflies of the Police Coulee area, Alberta. Blue Jay 43:213-23.

51. PYLE, R.M. 1981. The Audubon Society field guide to North American butterflies. Chanticleer Press, New York. $916 \mathrm{pp}$.

52. ROYER, R.A. 1988. Butterflies of North Dakota: an atlas and guide. Minot State Univ. Science Monograph No. $1.916 \mathrm{pp}$.

53. SCOTT, J.A. 1986. The butterflies of North America: a natural history and field guide. Stanford Univ. Press, Stanford. 583 pp.

54. STRONG, W. and K. LEGGATT. 1981. Ecoregions of Alberta. Alberta Energy and Natural Resource. 64 pp.

55. THORMIN, T.W., N.G. KONDLA and C.D. BIRD. 1980. Further records of skippers and butterflies from the Milk River - Lost River area of southeastern Alberta. Blue Jay 38:5-10.

56. TILDEN, J.W. and A.C. SMITH. 1986. A field guide to the western butterflies. Houghton Mifflin, Boston. 370 pp.

57. WHITEHOUSE, F.C. 1918. A week's collecting on Coliseum Mountain, Nordegg, Alta. Can. Ent. 50:1-7.

58. WOLLEY DOD, F.H. 1901. Preliminary list of the macrolepidoptera of Alberta, N.W.T. Can Ent. 33:40-42, 155-72.

59. - 1908a. Argynnis astarte Doubl.Hew., and other high mountain butterflies. Entomological News 40:108-14.

60. - 1908b. Further notes on Alberta Lepidoptera. Can. Ent. 40:181-93.

On butterfly migration: "On September 25, 1981, I observed approximately 6,000 Monarchs, 4,000 Red Admirals, 4,000 Question Marks, and 2,000 Mourning Cloaks moving south through a 10-foot wide path adjacent to the beach at Riis Park, Brooklyn, New York." Jeffrey Glassberg, Butterflying Through Binoculars.

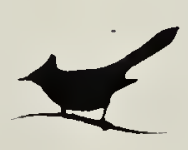

Spiders are the major predators of butterflies. R.M. Pyle. 1984. Audubon Society handbook for butterfly watchers. Scribner's, New York. 